\title{
Determination of Pollution Load Capacity Using QUAL2Kw Program on The Musi River Palembang
}

\author{
Handayani Lestari ${ }^{1}$, Riyanto Haribowo² ${ }^{2}$ Emma Yuliani ${ }^{2}$, \\ ${ }^{1}$ Environment and Water Resources Division, Nippon Koei Co., Ltd, Jakarta Selatan, \\ 12160, Indonesia \\ ${ }^{2}$ Water Resources Engineering Department, Universitas Brawijaya, Malang, 65145, \\ Indonesia \\ tariprojects@gmail.com
}

Received 23-07-2019; revised 12-08-2019; accepted 27-09-2019

\begin{abstract}
The Object of this research is a river named Musi, located in Palembang City, South of Sumatera, which is one of the longest and the biggest river in Indonesia. The condition of water quality in this river must be concerned because the high demand is not balanced with a good water quality. So, the aim of this study is to determine the value of the pollution load capacity, which is useful for consideration to government on water quality improvement policy. QUAL2Kw is used as an application to calculate the pollution capacity which entered to each river segment. There are 3 scenarios in this study, simulation 1 is calibrated model, simulation 2 is maximum of pollutant load condition, and simulation 3 is minimum of pollutant load condition. The value of pollutant load capacity is obtained from the difference between simulation 2 and simulation 3. The results show that the pollution load capacity on Musi River (particularly segment Pulokerto - PT. Baja Baru) in 2016 sequentially $12948 \mathrm{kgDO} /$ day, 25205 $\mathrm{kgBOD}_{5} /$ day, $3207 \mathrm{~kg} / \mathrm{NH}_{3}-\mathrm{N}$ day, $642 \mathrm{~kg} \mathrm{PO}_{4} /$ day.
\end{abstract}

Keywords: Water Quality, Pollution Load, River, Qual2KW

\section{Introduction}

Musi River is one of the main river in South Sumatra and widely used to meet the needs of the people of Palembang. Along the river with a length of $750 \mathrm{~km}$ and 300 meters wide stands a number of industries such as PT. Hevea MK II, PT. Badja Baru and many more [10]. Over time, the number of residents in the city of Palembang has increased, of about 1,5 million people [2], means that the need of clean water is around 1,9 million/l/person/day. The fact is, $70 \%$ water in Musi River is contaminated by domestic waste, and 30\% else contaminated by industrial waste [10]. The changes of land use around the Musi river border that affect the condition of the water quality of the river itself. This situation raises concerns about the decline in water quality, considering the use and utilization of this river is so high $[6,8,12]$. Therefore, the calculation of Pollution Load Capacity is needed for the consideration to manage water quality improvement on the next policy of government $[5,11]$. The first step to determine the value of pollution load capacity is collecting the water quality data, hydraulics data, and effluent which goes to the river [7]. Nest is entering the data to worksheet of QUAL2Kw. The result of this step is a model in graphical form. Then the model has to be calibrated by trial and error the coefficient value 
[3]. Based on the above problem, the aim of this study is to determine the value of the pollution load capacity.

\section{Material and Methods}

The method in determining the pollution load capacity in this study is a computational method using QUAL2Kw program. Secondary data collected include maps, river water quality data, river hydraulic conditions, water quality point source, population of Palembang City and meteorological conditions [4]. The water quality data, maps, river hydraulic condition, water quality source are obtained from Sanitation and Environmental Offices. While the population data of Palembang City is obtained from Central Agency of Statistics. The next step is determining the segments. After the segment is reached, the data that has been obtained is then entered into the QUAL2Kw program for model formation [1].

\subsection{Segmentation}

In this study the Musi River that will be examined is the start of the Pulokerto to PT. New Badja is about $7.1 \mathrm{~km}$ from the total length of Kalimas of approximately $750 \mathrm{~km}$. There will be 3 segments in this research. The division of this segment is based on input from the place for sampling, curves, changes in river dimensions and input from pollutant sources.

\subsection{Modelling}

After the data is entered and QUAL2Kw is executed, the calibration is required to be able to process the model simulation. Model calibration is done by altering the water quality coefficients at works sheet rates or Reach Rates. The model is said to have been verified if it has approached the data. This can be known from the trends formed by the model matching the trend formed by the data on the graph.

\subsection{Simulation}

Calibrated models can be used to perform various simulation scenarios of river conditions. There are three simulation scenarios in this research. Scenario 1 is a simulation of the result of forming the model according to the existing condition. Scenario 2 is an existing data condition where the industrial waste consumption is assumed to have been processed so as to comply with the water quality standard of waste and also no domestic waste entering the river body. Scenario 3 is a simulation where the state of the river is filled with pollutant load, where industrial waste and domestic waste enter the river body.

\subsection{Calculation of Load Pollution and Load Capacity}

Pollution Load Capacity of river is obtained from scenario 2 and scenario 3. From each scenario is taken the data of the debit and pollutant concentration of simulation result from Sources Summary worksheet. Then determine the value of pollutant load by multiplying the debit and pollutant concentration. The total river pollution load from scenario 2 and 3 then will be calculated to obtain the value of Load Capacity [9]. The calculation of pollution load is done by multiplying the large concertation into the river $(\mathrm{mg} / \mathrm{L})$ with the amount of river flow discharge $(\mathrm{m} / \mathrm{sec})$. The calculation of pollution load can be calculated by the following formula:

$$
\text { Pollution Load }(\mathrm{kg} / \text { day })=\text { Flow }(\mathrm{m} / \mathrm{s}) \times \text { Concentration }(\mathrm{mg} / \mathrm{l}) \times 86.4
$$

\section{Result and Discussion}

\subsection{Segmentation}

This research will analyse Musi River with length about $7.1 \mathrm{~km}$ from upstream (Pulokerto) to downstream (PT. Badja Baru). In this case, the river is divided into 3 segments starting from upstream (kilometres 7.01) downstream (kilometres 0.0 ). This river segmentation is done for modelling purposes. The division of this segment is based on inputs from the tributaries, the location for sampling, turns, changes in river dimensions and input from pollutants. This is the basis of the segment determination to get 3 segments that can be seen in Figure 1. Elevation measurement using google earth help. Segment division of research area in detail can be seen in Table 1 below. 
Table 1. Segmentation of Musi River Palembang

\begin{tabular}{cccc}
\hline \multirow{2}{*}{ Reach } & Kilometer (From & \multicolumn{2}{c}{ Elevation } \\
\cline { 3 - 4 } & Downstream) & Upstream (m) & Downstream (m) \\
\hline (Upstream) Point 1 - Point 2 & $7.1-5.05$ & 4.88 & 3.96 \\
\hline Point 2 - Point 3 & $5.05-2.05$ & 3.96 & 2.75 \\
\hline Point 3 - Point 4 & $2.05-0$ & 2.75 & 2.15 \\
\hline
\end{tabular}

3.1.1. Reach 1, Point 1 - Point $2(2.05 \mathrm{~km})$

Point Segment 1 - Point 2 is the first segment in the model formation for Musi Palembang. Point 1 (upstream) is an agro-cultural area. While Point 2 is an area that is not so far from the outlet of an industry called PT. Hevea MK II. The distance in this $1-2$ segment is $2.05 \mathrm{~km}$. This first segment is divided based on the input of the tributary to the Musi River and also the input of waste from the industry. This area is dominated by agricultural fields, and plantation. It proved by the concentration of phosphate $\left(\mathrm{PO}_{4}\right)$ in point 1 is $0.90 \mathrm{mg} / \mathrm{L}$, which is the highest number compared with the $\mathrm{PO}_{4}$ in the other reaches. The average value of $\mathrm{PO}_{4}$ in this area is around $0.75 \mathrm{mg} / \mathrm{L}$, where the quality standard class II permits the maximum value of $\mathrm{PO}_{4}$ in some river is only $0.20 \mathrm{mg} / \mathrm{L}$. Moreover, the $\mathrm{NH}_{3}-\mathrm{N}$ value is also increased. It shows that the harmful toxicant begins to arised, about $0.41 \mathrm{mg} / \mathrm{L}$ to $0.56 \mathrm{mg} / \mathrm{L}$. Map of point 1 - Point 2 can be seen in Figure 1

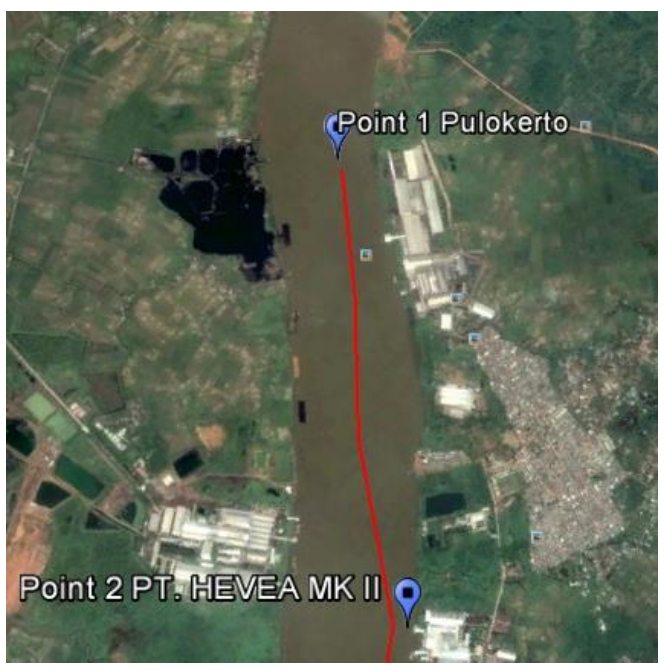

Figure.1. Reach 1 (from Pulokerto to PT. Hevea $M K$ II)

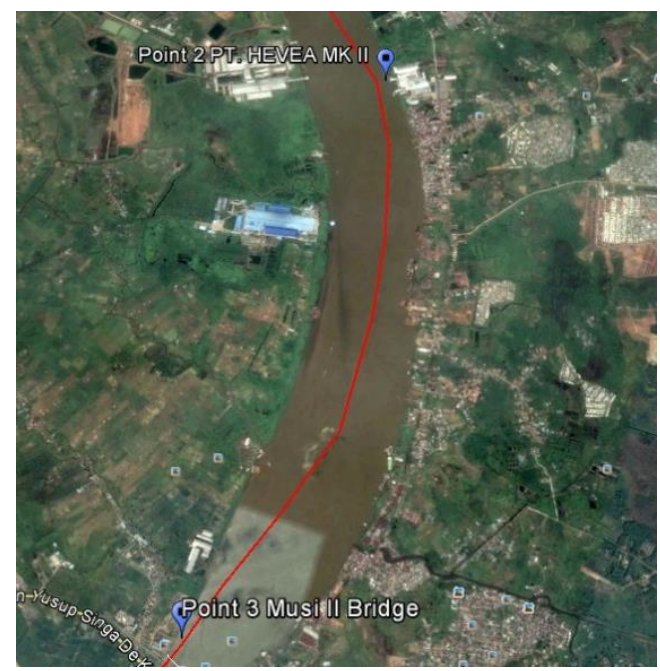

Figure.2. Reach 2 (from PT. HEVEA MK II to Musi II Bridge)

\subsubsection{Reach 2, Point 2 - Point $3(3.00 \mathrm{~km})$}

Segment Point 2 - Point 3 is the second segment in modelling for Musi Palembang. As mentioned earlier, Point 2 is an area affected by the output of industrial waste (PT. Hevea MK II). While Point 3 is Musi II Bridge, where sampling is easy to do. The distance on this 2-3 segment is $3.00 \mathrm{~km}$. This second segment is determined based on industrial waste input at Point 2 and the easy access of water quality sampling at Point 3. The value of DO is begin to decreased, about $6.0 \mathrm{mg} / \mathrm{L}$ to $5.7 \mathrm{mg} / \mathrm{L}$. in this reach. On the contrary, the $\mathrm{BOD}_{5}$ value is begin to increased, about $4.1 \mathrm{mg} / \mathrm{L}$ to $4.4 \mathrm{mg} / \mathrm{L}$. It can be conclude that the oxygen content is getting worse. It may cause by the affection from industrial waste water output, PT. Hevea MK II. The Map of point 1 - Point 2 can be seen in Figure 2 below.

\subsubsection{Reach 3, Point 3 - Point $4(2.05 \mathrm{~km})$}

Segment Point 3 - Point 4 is the third segment in forming a model for Musi Palembang. Point 3 as described previously, is Musi II Bridge where access to sampling is easy to do. While Point 4 is a region that is not so far from the outlet of an industry named PT. Badja Baru. The distance in this 3-4 segment 
is $2.05 \mathrm{~km}$. This third segment is divided based on the easy access of water quality sampling at Point 3 and also the industrial waste input at Point 4. Getting down to downstream, the oxygen content is also getting worse than before. The value of $\mathrm{BOD}_{5}$ in point 3 is $4.23 \mathrm{mg} / \mathrm{L}$, and in point 4 is $4.70 \mathrm{mg} / \mathrm{L}$. it may be caused by domestic waste output and the affection of industrial waste output from the previous reach. Map of point 1 - Point 2 can be seen in Figure 3 below.

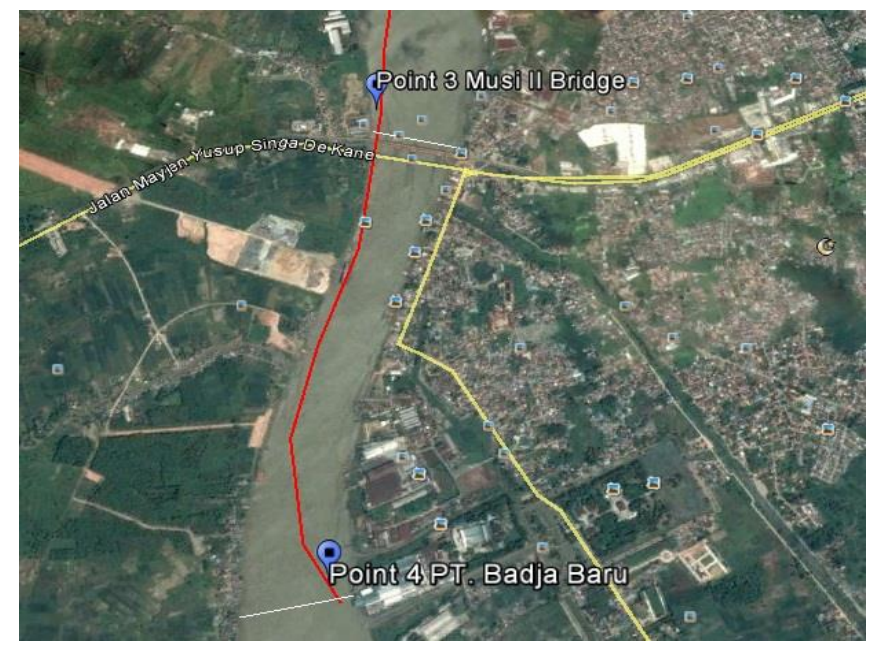

Figure.3. Reach 3 (Jembatan Musi II to PT. Badja Baru)

\subsection{Model Formation of QUAL2Kw Version 5.1}

The stage of model formation is done after the segmenting step. The model formation of the Musi River Palembang will execute the hydraulics data of the Musi River, and the water quality data of the Musi River. The data that input to QUAL2kw version 5.1 worksheet included the general data on the river, such as river name, sampling time and so on, water quality data on headwater, segment data, point sources and diffuse sources (nonpoint sources) data Hydraulic rivers (speed, depth and debut of the river), water quality data of water bodies $\left(\mathrm{pH}, \mathrm{BOD}, \mathrm{NH}_{3}-\mathrm{N}, \mathrm{PO}_{4}\right.$, and $\left.\mathrm{DO}\right)$, then supporting data such as cloud cover data, wind speed, and dew temperature. In modelling, non-source pollutant sources are industrial wastewater, where the drainage channels go directly to the Musi River. The river quality parameters measured and modelled must be in accordance with the parameters in the QUAL2Kw program, can be seen in the following table:

Table 2. Water Quality Parameters in QUAL2Kw Program

\begin{tabular}{ccc}
\hline No & Parameter & Parameter Name in QUAL2Kw \\
\hline 1 & $\mathrm{pH}$ & $\mathrm{pH}$ \\
\hline 2 & Temperature $\left({ }^{\circ} \mathrm{C}\right)$ & Temperature $\left({ }^{\circ} \mathrm{C}\right)$ \\
\hline 3 & $\mathrm{DO}(\mathrm{mg} / \mathrm{L})$ & Dissolved Oxygen $(\mathrm{mg} / \mathrm{L})$ \\
\hline 4 & $\mathrm{BOD}(\mathrm{mg} / \mathrm{L})$ & CBOD fast $(\mathrm{mg} / \mathrm{L})$ \\
\hline 5 & $\mathrm{COD}(\mathrm{mg} / \mathrm{L})$ & Generic Constituent $(\mathrm{mg} / \mathrm{L})$ \\
\hline 6 & $\mathrm{TSS}(\mathrm{mg} / \mathrm{L})$ & $\mathrm{ISS}(\mathrm{mg} / \mathrm{L})$ \\
\hline 7 & $\mathrm{NH}_{3}-\mathrm{N}(\mathrm{mg} / \mathrm{L})$ & $\mathrm{NH}_{4}(\mu \mathrm{g} / \mathrm{L})$ \\
\hline 8 & $\mathrm{PO}_{4}(\mathrm{mg} / \mathrm{L})$ & Inorganic $\mathrm{P}(\mu \mathrm{g} / \mathrm{L})$ \\
\hline 9 & $\mathrm{NO}_{3}(\mathrm{mg} / \mathrm{L})$ & $\mathrm{NO}_{3}(\mu \mathrm{g} / \mathrm{L})$ \\
\hline 10 & $\mathrm{Total} \mathrm{Coliform}$ & $\mathrm{Pathogen}$ \\
\hline
\end{tabular}

\subsubsection{Calibration of Hydraulic Model}

Before performing a scenario simulation, the already built model needs to be calibrated. Model calibration is carried out by the data model approaching the input data that has been entered into the 
program due to time differences and variations of data. The calibration model is divided into 2 calibrations, that are calibration hydraulic data and calibration of water quality data. Hydraulic data calibration is done by entering data of Musi River (Pulokerto - PT. Badja Baru) into QUAL2Kw worksheet, headwater, reach, point sources (hydraulic data), diffuse sources (hydraulic data, hydraulics data, and temperature data) Then input next click "Run VBA" to run and can be done trial and error for the model formed of hydraulic parameters in accordance with the inputted data.

In conducting trial and error for the hydraulic, the changed data varies. Models of speed and depth of Musi Palembang River are calibrated by changing the value on the worksheet reach. Where on the worksheet is done trial and error on the column manning formula. The river flow model is influenced by both incoming and outgoing debit data into the Musi River included in the worksheet point sources and diffuse sources. In conducting river flow model calibration, trial and error is performed on the diffuse source worksheet.

In the worksheet reach there are coordinate data, distance, elevation, and hydraulic model. In the column hydraulic model there is a weir column, column rating curves and manning formula. The weir column is filled when there is a waterfall in a river, but in Musi there is no plunge, so the weir column does not need to be filled. The rating curves and manning formulas are columns for determining calculations at the speed and depth of the stream. Both models do not have to be filled both, but selected one of the models. The selected model is Manning formula, this is because the value in Manning formula is easier to use for river Modeling in inputting data. In the Manning column there is a data slope of the river, the coefficient of Manning, and the width of the river. The Musi River hydraulic data is inputted to the worksheet hydraulics data containing the debit data, depth, and speed, can be seen in Table 3 and 4 below:

Table 3. Worksheet Reach

\begin{tabular}{|c|c|c|c|c|c|c|c|c|}
\hline \multicolumn{9}{|c|}{ Hydraulic Model (Weir Overrides Rating Curves; Rating Curves Override Manning Formula) } \\
\hline \multicolumn{4}{|c|}{ Rating Curves } & \multicolumn{5}{|c|}{ Manning Formula } \\
\hline \multicolumn{2}{|c|}{ Velocity } & \multicolumn{2}{|c|}{ Depth } & \multirow{2}{*}{$\begin{array}{c}\text { Channel } \\
\text { Slope }\end{array}$} & \multirow{2}{*}{$\frac{\text { Manning }}{\mathrm{n}}$} & \multirow{2}{*}{$\frac{\text { Bot Width }}{\mathrm{m}}$} & \multirow{2}{*}{$\begin{array}{c}\text { Side } \\
\text { Slope }\end{array}$} & \multirow{2}{*}{$\begin{array}{l}\text { Side } \\
\text { Slope }\end{array}$} \\
\hline Coefficient & Exponent & Coefficient & Exponent & & & & & \\
\hline 1.6800 & 0.000 & 6.0000 & 0.000 & 0.000446 & 0.0700 & 419.00 & 0.00 & 0.00 \\
\hline 1.4200 & 0.000 & 6.1500 & 0.000 & 0.000446 & 0.0700 & 464.00 & 0.00 & 0.00 \\
\hline 2.0700 & 0.000 & 6.2000 & 0.000 & 0.000407 & 0.0180 & 330.00 & 0.00 & 0.00 \\
\hline 1.8600 & 0.000 & 6.4700 & 0.000 & 0.000298 & 0.0160 & 279.00 & 0.00 & 0.00 \\
\hline
\end{tabular}

Table 4. Worksheet Hydraulics Data

\begin{tabular}{cccc}
\hline Distance & Q-data & H-data & U-data \\
\hline$(\mathrm{km})$ & $\mathrm{m}^{3} / \mathrm{s}$ & $\mathrm{m}$ & $\mathrm{m} / \mathrm{s}$ \\
\hline 7.100 & 4337.490 & 6.000 & 1.680 \\
\hline 5.050 & 3984.150 & 6.150 & 1.420 \\
\hline 2.050 & 4952.710 & 6.280 & 2.070 \\
\hline 0.000 & 2156.060 & 6.470 & 1.860 \\
\hline
\end{tabular}

\subsubsection{Calibration of Water Quality Model}

After the hydraulic data calibration model is in accordance with the desired data, then the next calibration of water quality data streams in each segment. In water quality calibration, data that has been inputted into WQ data worksheet, point sources, diffuse sources, and supporting data such as air temperature, dew point temperature, wind speed, cloud cover, shade, and diesel.

In calibrating the water quality data of the river, the data to be changed in value is the data on the worksheet reach rates. Where on the worksheet is done trial and error on the coefficient of each parameter. Range coefficient value of each parameter can be seen in Table 5. The coefficient range is a corresponding number for rivers in a 4 seasons country. Therefore, calibration is needed to adjust the 
appropriate coefficients for the Musi River Palembang. In doing this calibration there is a possibility that the coefficient value is outside the range in the table below, because the condition of each river will be different.

Table 5. Coefficient Value of Calibration

\begin{tabular}{ccc}
\hline Coefficient Name & Unit & Value Range \\
\hline Reaeration & day $^{-1}$ & $0,02-3,4$ \\
\hline ISS Settling Velocity & m/day & $0-2$ \\
\hline CBOD Oxidation Rate & day $^{-1}$ & $0,02-4,2$ \\
\hline $\mathrm{NH}_{4}$ Nitrification Rate & day $^{-1}$ & $0-10$ \\
\hline $\mathrm{NO}_{3}$ Denitrification Rate & day $^{-1}$ & $0-2$ \\
\hline $\mathrm{NO}_{3}$ Sed. Denitri Transfer Coeff. & day $^{-1}$ & $0-1$ \\
\hline $\mathrm{PO}_{4}$ Settling Velocity & m/day & $0-2$ \\
\hline
\end{tabular}

The fitness value is the control value generated when the QUAL2Kw program finishes running. Good fitness value is at susceptible 0 to 1 . If more than that, there may be errors in the input data so as to make the fitness value more than 1 . And in this research, the calibration obtained fitness value of 0.65 . It means that the process of input data has already correct because the fitness value is still below to 1 . The results of hydraulic calibration can be seen in the following figure below:

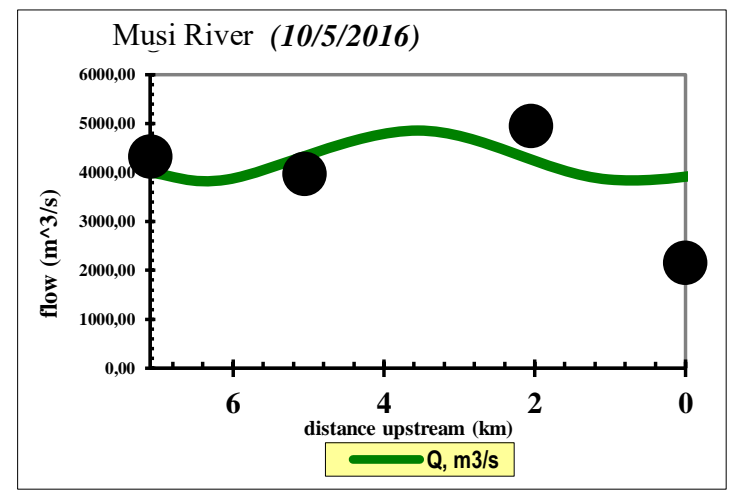

Figure 5. Comparison of Stream Flow Models and Data

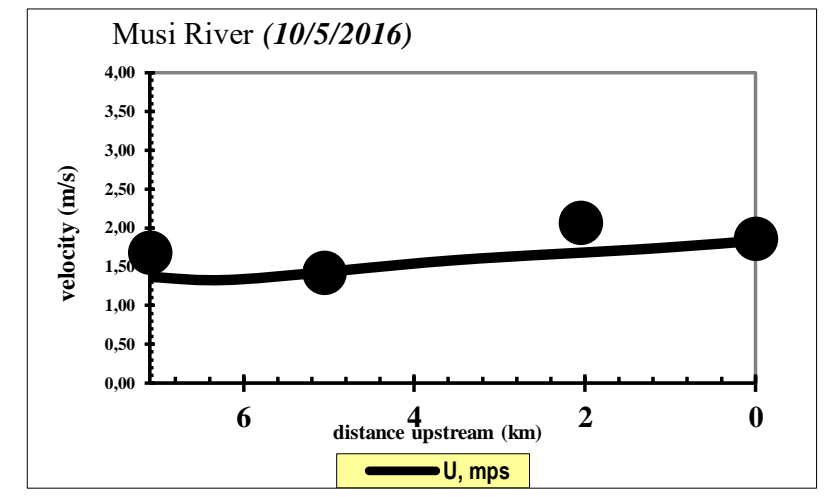

Figure 6. Comparison of Velocity Models and data

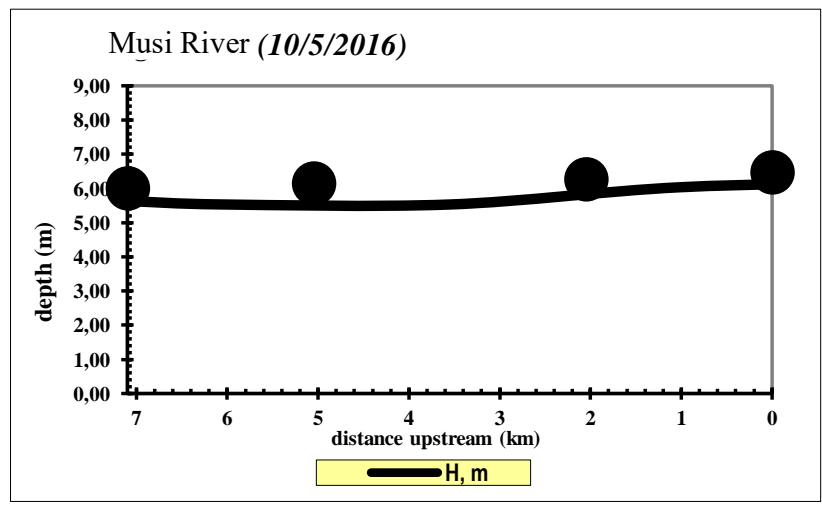

Figure 7. Comparison of Depth Models and Data

From Figure 5, 6 and 7 above, The data trends in the graph above are indicated by dots, and the model trend is indicated by the line. It can be seen that the trend of debit model, trend of depth model, and trend of velocity of QUAL2Kw running results is similar to the trend of existing data. 


\subsection{Water Quality Simulation \\ 3.3.1. Simulation 1}

In simulation 1 it aims to calibrate water quality data to be used for other simulations. The results of this simulation obtained some parameters such as $\mathrm{DO}, \mathrm{BOD}, \mathrm{NH}_{3}-\mathrm{N}$, and Phosphate, with a variety of circumstances, some exceed the quality standard, while not. In doing this simulation 1 is done trial and error, for calibration of water quality data at worksheet reach rates.

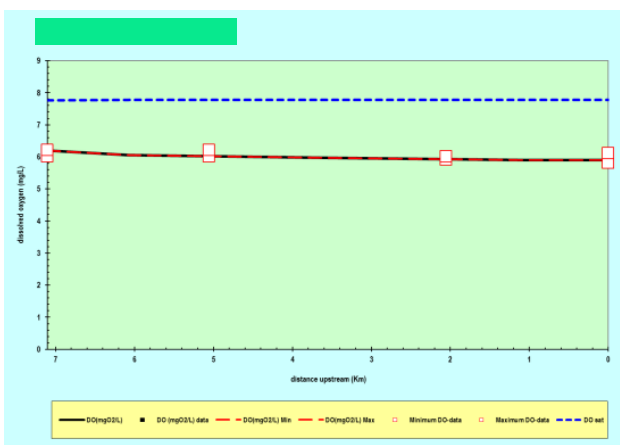

Figure 8. Comparison of Dissolved Oxygen (DO) Models and Data

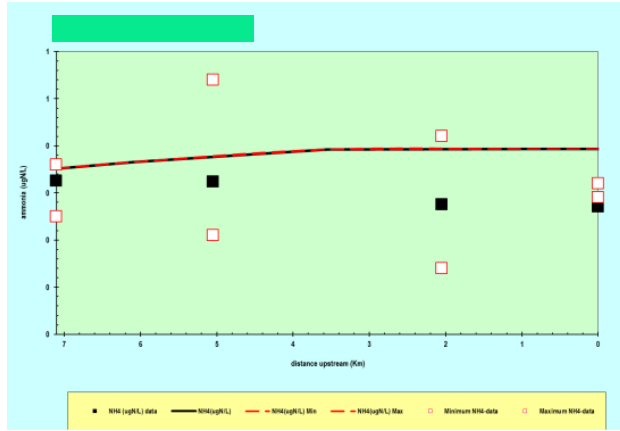

Figure 10. Comparison of Ammonia Nitrogen $\left(\mathrm{NH}_{3}-\mathrm{N}\right)$ Models and Data

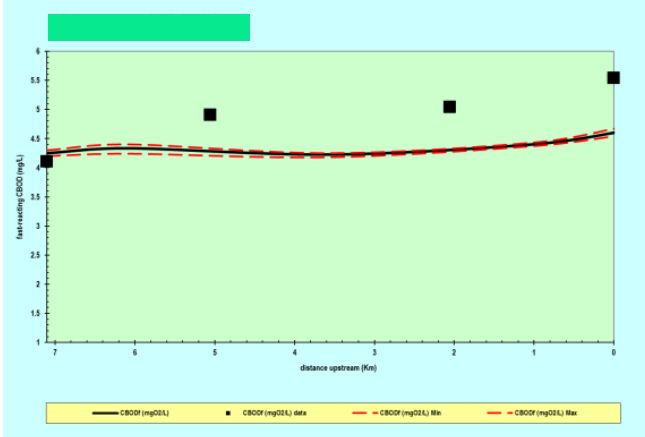

Figure 9. Comparison of Biological Oxygen Demand $\left(\mathrm{BOD}_{5}\right)$ Models and Data

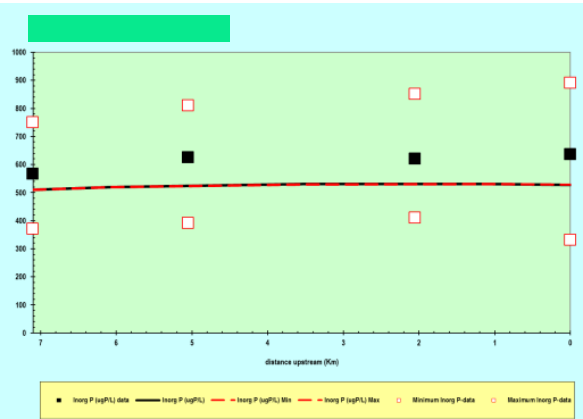

Figure 11. Comparison of Phosphate $\left(\mathrm{PO}_{4}\right)$ Models and Data

Based on the results of simulation 1, it can be seen that the trend of DO model running QUAL2Kw is similar to the existing data trend DO. The value of DO increasingly downstream tends to decrease. But, the value of $\mathrm{BOD}_{5}$ increasingly to the downstream tend to increase. This condition is in contrast to the previous DO value. And it can be seen that $\mathrm{NH}_{3}-\mathrm{N}$ model trend and trend of Phosphate of QUAL2Kw running result is similar to existing data trend.

\subsubsection{Simulation 2}

Simulation 2 is a condition where trial and error at point source up to downstream water quality value in accordance with the limit of class II water quality standard. The quality standard in use is Government Regulation no. 82. 2001 [10]. The profile of river water quality can be seen in Figure 12 to Figure 15. This quality profile is intentionally made to meet the quality standard. The assumption made is the amount of pollution load. The results of this simulation can be used to calculate the pollution load capacity, i.e. the amount of load that may be discharged into the river without causing polluted river water (not exceeding the quality standard). 


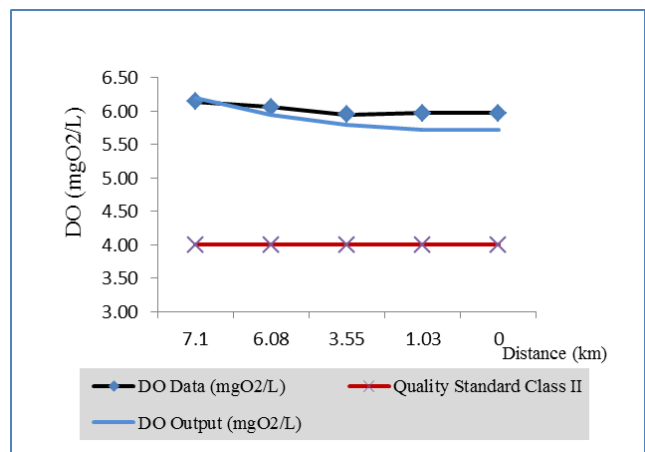

Figure 12. Water quality profile of Musi River Parameters DO Simulation 2

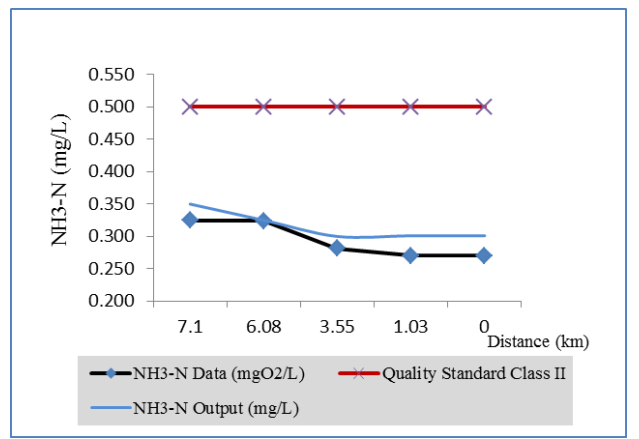

Figure 14. Water quality profile of Musi River Parameter $\mathrm{NH}_{3}-\mathrm{N}$ Simulation 2

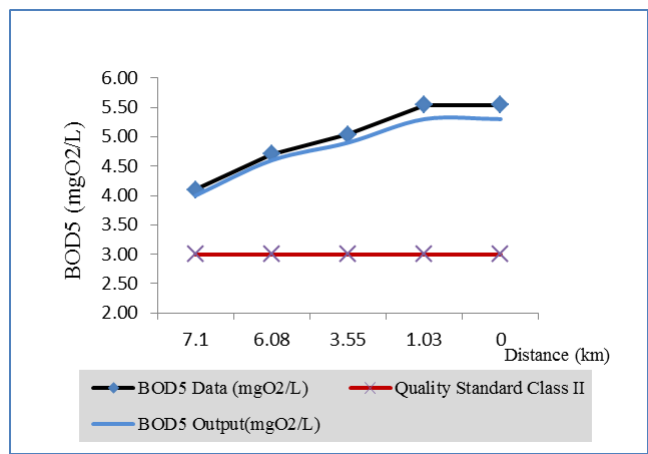

Figure 13. Water quality profile of Musi River Parameters BOD 5 Simulation 2

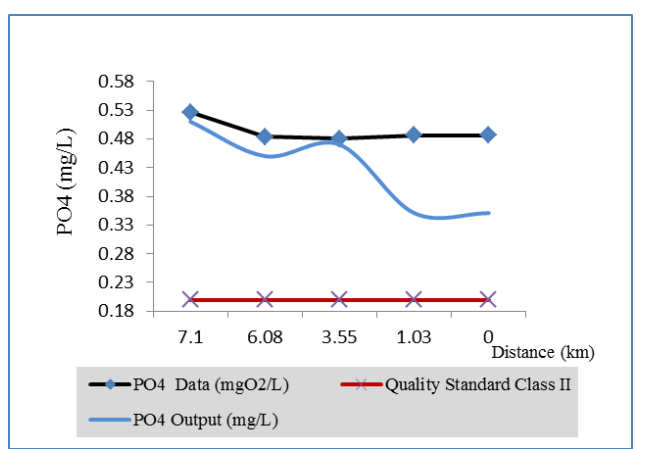

Figure 15. Water quality profile of Musi River Parameter $\mathrm{PO}_{4}$ Simulation 2

The results of simulation 2 is a high value of DO. This means that there is still a lot of oxygen content in the waters of the river Musi point Pulokerto up to PT. New Badja. The value of DO tends to fall from point 2 to point 4 , where from point 2 there begins waste discharges from 2 major industries of crumb rubber. Where the $\mathrm{BOD}_{5}$ value is still above the quality standard. $\mathrm{BOD}_{5}$ value is also higher towards downstream, this condition is in contrast to the previous DO condition which actually decreased.

In simulation 2, the waste discharge load is fully loaded, so the value of $\mathrm{BOD}_{5}$ value is quite significant compared to simulation 1 . Then the value of $\mathrm{NH}_{3}-\mathrm{N}$ is also below from the quality standard value. $\mathrm{NH}_{3}-\mathrm{N}$ or commonly called ammonia nitrogen is a parameter that can be an indicator of ammonia toxicity that may harm aquatic life. It means the output of fisheries produced in vulnerable Pulokerto PT. Badja Baru is still safe from aquatic disease because it is still below the standard value. And the reason why the $\mathrm{PO}_{4}$ value is above from the standard quality may because there's still an influence from the fertilizer of agricultural area. The highest phosphate value still exists in the first point, namely the point of Pulokerto where the area is indeed dominated by plantations and agriculture.

\subsubsection{Simulation 3}

The simulation 3 is done by eliminating pollutant load (point source), and data in headwater according to class II quality standard. Similarly, non-point source quality is considered good, equal to the quality standard of waste water. Under conditions without input this pollution load, can know the amount of the minimum river pollution load burden with the maximum contamination load according to the quality standard. The results of simulation 3 can be seen in Figure 16 to Figure 19. The simulation results show that the removal of pollution sources along the river, the water quality of the meet the quality standards in all segments. 


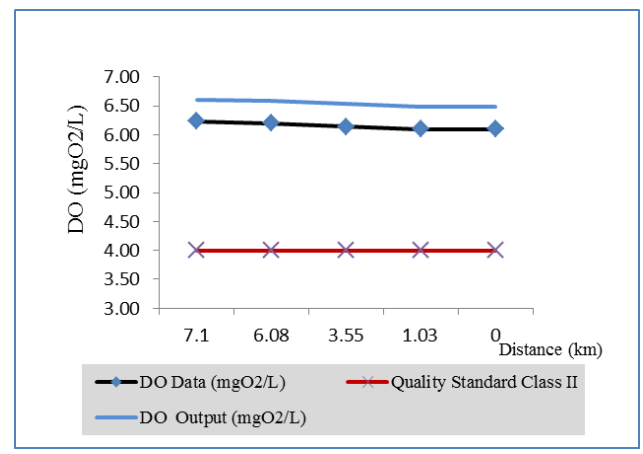

Figure 16. Water quality profile of Musi River Parameters DO Simulation 3

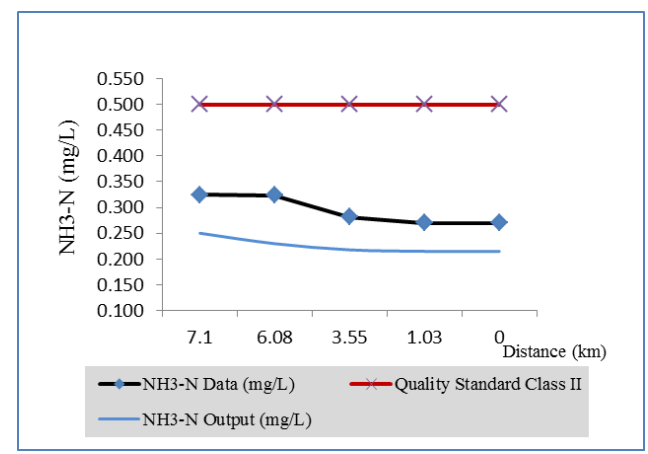

Figure 18. Water quality profile of Musi River Parameter $\mathrm{NH}_{3}-\mathrm{N}$ Simulation 3

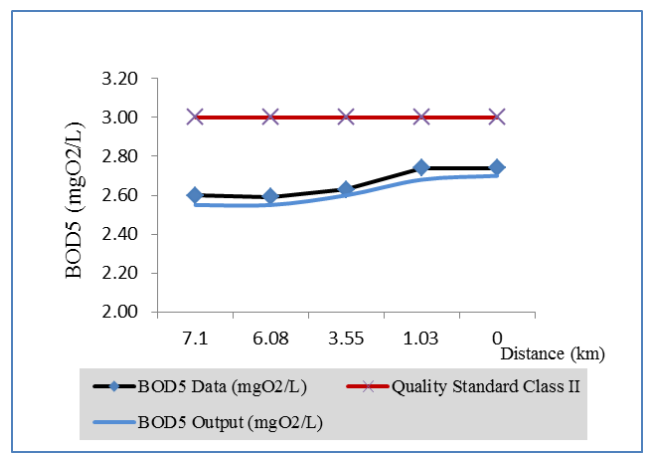

Figure 17. Water quality profile of Musi River Parameters $\mathrm{BOD}_{5}$ Simulation 3

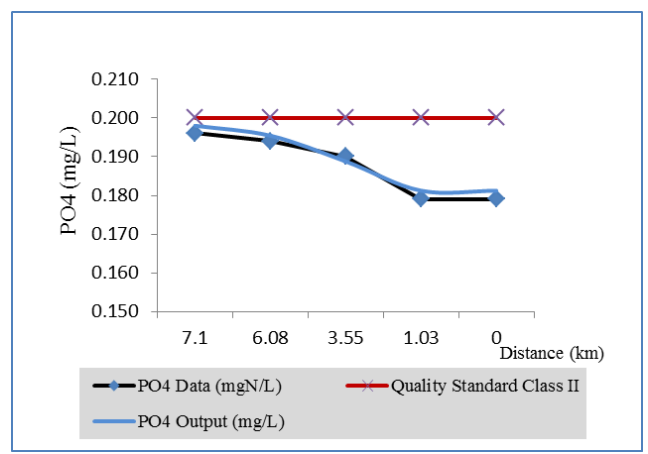

Figure 19. Water quality profile of Musi River Parameter $\mathrm{PO}_{4}$ Simulation 3

Based on the result of simulation 3, that the value of DO is above the standard. The value of DO tends not to increase significantly or decrease significantly. In the simulation 3 is in the condition of the load discharged of waste considered no entry into the river body. Then the value of DO so tend to be constant. Whereas, in $\mathrm{BOD}_{5}, \mathrm{NH}_{3}-\mathrm{N}$, and $\mathrm{PO}_{4}$ graphic, the value is below from the standard. The condition of $\mathrm{BOD}_{5}$ is different when compared with the condition of $\mathrm{BOD}_{5}$ in simulation 2 which in overall value is above the standard. This is due to the effect of discharge of waste discharges entering the river body, so the $\mathrm{BOD}_{5}$ condition in simulation 3 is better than the condition in simulation 2 . in $\mathrm{NH}_{3}-\mathrm{N}$ graphic, the value is also below from the standard. Indeed, when compared with the simulation 2 , still equally below the quality standard because it is in the existing conditions even the value of ammonia nitrogen is not too high. However, by weight of the numbers, the nitrogen ammonia value in simulation 3 remains lower than the simulation 2. Of course this has its effect from discharging the waste discharge load. The smaller the value of ammonia nitrogen the less likely the fish or biota in the river is poisoned. And for $\mathrm{PO}_{4}$, there is a significant decrease of phosphate starting from the 2 nd point, because the waste discharges in the river body are increasingly to downstream is industrial and domestic waste.

\subsubsection{Simulation 4}

In simulation 4, will try to influence the discharge of water quality on point Pulokerto to PT. Badja Baru. The maximum and minimum debit data to be used is the maximum discharge data available throughout the study site (Pulokerto-PT Badja Baru). Maximum and minimum debit data in the input on the headwater worksheet alternately to determine the effect that occurred. 


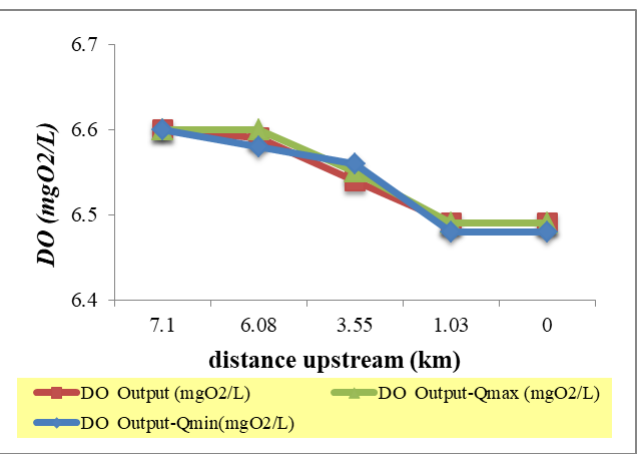

Figure 20. Water quality profile of Musi River Parameters DO Simulation 4

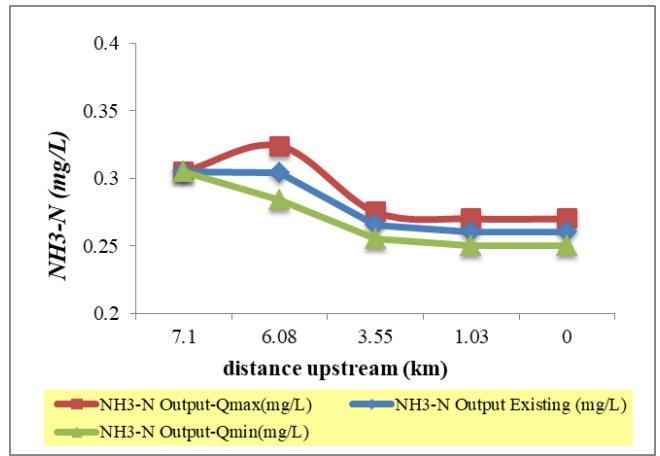

Figure 22. Water quality profile of Musi River Parameter $\mathrm{NH}_{3}-\mathrm{N}$ Simulation 4

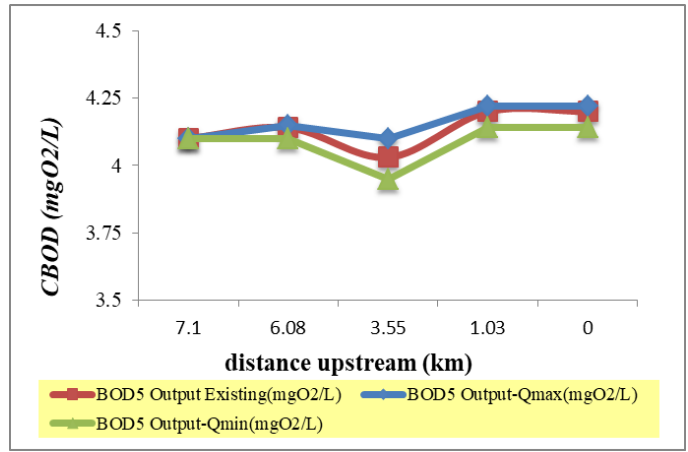

Figure 21. Water quality profile of Musi River Parameters $\mathrm{BOD}_{5}$ Simulation 4

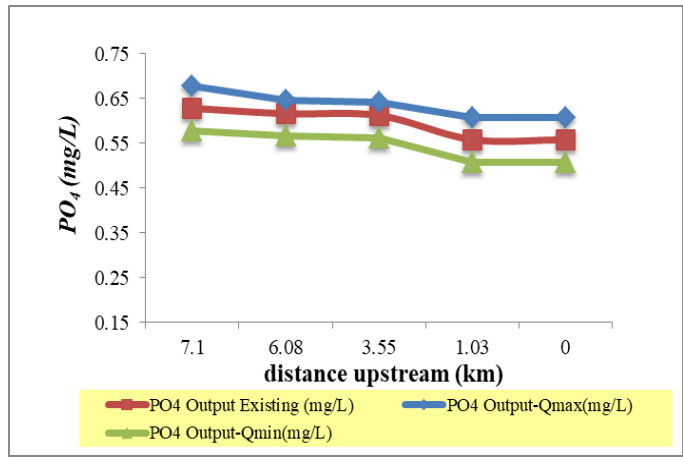

Figure 23. Water quality profile of Musi River Parameter $\mathrm{PO}_{4}$ Simulation 4

\subsection{Calculation of Pollution Load Capacity}

From the data of the simulation of water quality, the data is used to calculate the capacity of pollution load on the Musi River from the Pulokerto segment to PT. New Badja. The calculation of the pollution load capacity will use the data generated on the Source Summary worksheet which is the result of the calculation of debit pollution load and the water quality of each segment. The calculation of the pollution load capacity using simulation 2 and 3, based on the results of the two simulations will be obtained the calculation of load pollution capacity by the difference of simulation result 2 (full pollution load) and simulation 3 (load without pollution). The source summary table for simulation 2 can be seen in Table 6 . Whereas, for the source summary for simulation 3 , the overall result is 0 , because in simulation 3 assumed that there's no pollutants enter to the river. Then, the calculation of pollution load is obtained from multiplication of inflow and concentrations value on each parameter. These calculations of pollution load on each parameter can be seen in table 7 to 11 .

Table 6. Result Source Summary Simulation 2

\begin{tabular}{cccccccccccc}
\hline Inflow & Temp & Cond & ISS & Oxygen & CBODs & CBODf & No & NH4 & NO3 & Po & Inorg P \\
\hline cms & $\mathbf{C}$ & uS/cm 25C & $\mathbf{m g D / L}$ & $\mathbf{m g O 2} / \mathbf{L}$ & $\mathbf{m g O 2} / \mathbf{L}$ & $\mathbf{m g O 2} / \mathbf{L}$ & $\mathbf{u g N / L}$ & $\mathbf{u g N} / \mathbf{L}$ & ugN/L & ugP/L & ugP/L \\
\hline 28.47 & 15.00 & 600.00 & 0.00 & 2.00 & 1.00 & 4.00 & 500.00 & 500.00 & 2000.00 & 100.00 & 100.00 \\
\hline 36.08 & 15.05 & 599.56 & 0.03 & 2.03 & 1.00 & 3.99 & 498.13 & 498.13 & 1992.52 & 9.63 & 9.63 \\
\hline 9.85 & 15.00 & 600.00 & 0.00 & 2.00 & 1.00 & 4.00 & 500.00 & 500.00 & 2000.00 & 100.00 & 100.00 \\
\hline
\end{tabular}

Table 7. Calculation of Pollution Load, Parameters DO

\begin{tabular}{ccccc}
\hline Reach & $\mathrm{km}$ & Flow $(\mathrm{m} / \mathrm{s})$ & DO $(\mathrm{mg} / \mathrm{L})$ & Pollution Load - DO $(\mathrm{kg} /$ day $)$ \\
\hline 1 & $7.1-5.05$ & 28.47 & 2.00 & 4920.00 \\
\hline 2 & $5.05-2.05$ & 36.08 & 2.03 & 6327.69 \\
\hline 3 & $2.05-0$ & 9.85 & 2.00 & 1702.08 \\
\hline
\end{tabular}


Table 8. Calculation of Pollution Load, Parameters BOD 5

\begin{tabular}{ccccc}
\hline Reach & $\mathrm{km}$ & Flow $(\mathrm{cm} / \mathrm{s})$ & BOD $_{5}(\mathrm{mg} / \mathrm{L})$ & Pollution Load - BOD $_{5}(\mathrm{~kg} /$ day $)$ \\
\hline 1 & $7.1-5.05$ & 28.47 & 4.00 & 9840.00 \\
\hline 2 & $5.05-2.05$ & 36.08 & 3.99 & 12421.71 \\
\hline 3 & $2.05-0$ & 9.85 & 4.00 & 3404.17 \\
\hline
\end{tabular}

Table 9. Calculation of Pollution Load, Parameter $\mathrm{NH}_{3}-\mathrm{N}$

\begin{tabular}{ccccc}
\hline Reach & $\mathrm{km}$ & Flow $(\mathrm{m} / \mathrm{s})$ & $\mathrm{NH}_{3}-\mathrm{N}(\mathrm{mg} / \mathrm{L})$ & Pollution Load $-\mathrm{NH}_{3}-\mathrm{N}(\mathrm{kg} /$ day $)$ \\
\hline 1 & $7.1-5.05$ & 28.47 & 0.50 & 1230.00 \\
\hline 2 & $5.05-2.05$ & 36.08 & 0.49 & 1552.71 \\
\hline 3 & $2.05-0$ & 9.85 & 0.50 & 425.52 \\
\hline
\end{tabular}

Table 10. Calculation of Pollution Load, Parameter $\mathrm{PO}_{4}$

\begin{tabular}{ccccc}
\hline Reach & $\mathrm{km}$ & Flow $(\mathrm{m} / \mathrm{s})$ & $\mathrm{PO}_{4}(\mathrm{mg} / \mathrm{L})$ & Pollution $\mathrm{Load}-\mathrm{PO}_{4}(\mathrm{~kg} /$ day $)$ \\
\hline 1 & $7.1-5.05$ & 28.47 & 0.100 & 246.000 \\
\hline 2 & $5.05-2.05$ & 36.08 & 0.099 & 310.542 \\
\hline 3 & $2.05-0$ & 9.85 & 0.100 & 85.104 \\
\hline
\end{tabular}

Table 11. Pollution Load Capacity in Musi River

\begin{tabular}{cccccc}
\hline Reach & $\mathrm{km}$ & $\mathrm{DO}(\mathrm{kg} /$ day $)$ & $\begin{array}{c}\mathrm{BOD}_{5} \\
(\mathrm{~kg} / \text { day })\end{array}$ & $\mathrm{NH}_{3}-\mathrm{N}(\mathrm{kg} / \mathrm{day})$ & $\begin{array}{c}\mathrm{PO}_{4} \\
(\mathrm{~kg} / \text { day })\end{array}$ \\
\hline 1 & $7.1-5.05$ & 4920.00 & 9840.00 & 1230.00 & 246.00 \\
\hline 2 & $5.05-2.05$ & 6327.69 & 12421.71 & 1552.71 & 310.54 \\
\hline 3 & $2.05-0$ & 1702.08 & 3404.17 & 425.52 & 85.10 \\
\hline
\end{tabular}

From the table above, can be seen that the largest capacity in the Musi River is in the segment (reach) 2 on each parameter. The potential source of pollution load in this segment comes from industrial and domestic waste (household) waste. The amount of pollution load capacity that has been obtained in this study results at any time may change but the changes are not so significant. The difference can be caused by the increasing amount of incoming waste, the number of segments, and the seasonal differences.

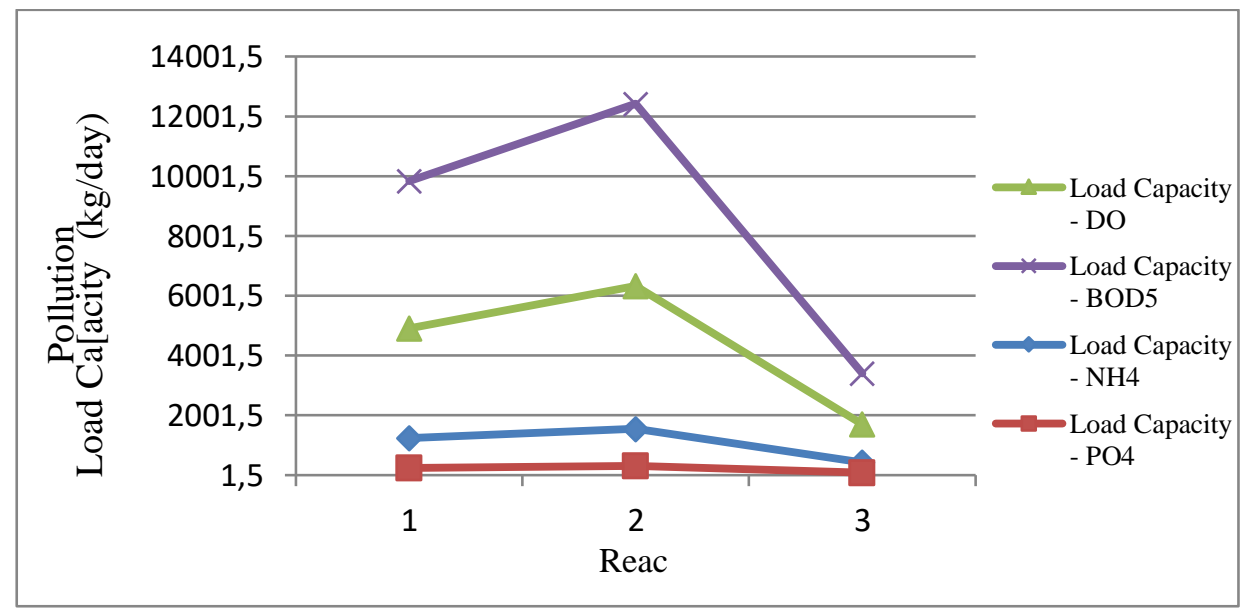

Figure 24. Pollution Load Capacity, Musi River Pulokerto-PT.Badja Baru)

\section{Conclusions}

The parameter of water quality which simulated are $\mathrm{DO}, \mathrm{BOD}_{5}, \mathrm{NH}_{3}-\mathrm{N}$, and $\mathrm{PO}_{4}$. Determination of river pollution load capacity can be done with several methods, one of which is computation method using QUAL2Kw program. This computer program works by analysing the simulation results of the river 
water quality model. Determination of pollution load capacity of Musi River in Pulokerto - PT. New Badja concluded that the capacity of pollution load of the river is still quite large with the capacity value as follows: $12,948 \mathrm{kgDO} /$ day, $25,205 \mathrm{kgBOD}_{5} /$ day, $3,207 \mathrm{~kg} / \mathrm{NH}_{3}-\mathrm{N}$ day, $642 \mathrm{kgPO}_{4} /$ day. Based on the result of application running, we can analyse and know the indicator numbers of each parameter to calculate the popullation load capacity. And for the future, this application can be used to see the quality of water river or the spread of pollution loads that exist. Therefore, by knowing the existing pollution capacity we can know which segments of the river that need improvement for the future.

\section{References}

[1] Brown, L.C., Barnwell, T.O., 1987. The Enhanced Stream Water Quality Models QUAL2E and QUAL2E-UNCAS (EPA/600/3-87-007). U.S. Environmental Protection Agency, Athens, GA, pp 189.

[2] Central Agency of Statistics. 2016. Palembang in Numbers. Palembang. (in bahasa Indoensia)

[3] Chapra, S.C., Pelletier, GJ (2003) QUAL2K: A Modeling Framework for Simulating River and Stream Water Quality (Beta Version): Documentation and Users Manual. Civil and Environmental Engineering Dept., Tufts University

[4] Hoesein. A. 1984. Water Quality and Irrigation System; Faculty of Engineering. Universitas Brawijaya. Malang. (in bahasa indonesia)

[5] Metcalf \& Eddy. 2003. Wastewater Engineering :Treatment Disposal Reuse. McGraw-Hill,Inc. New York.

[6] Mitsch \& Gosselink. 1994. Wet Land, In Water Quality Prevention, Identification and Management of Diffuse Pollution. Van Nostrand Reinhold,.New York

[7] Ray K. Linsey, Franzini , Joshep B. 1991. Water Resources Engineering ; Erlangga. Jakarta. (in bahasa indonesia)

[8] Riyanto H, Minami Y, Masahiko S, Tsuyoshi I, Koichi Y, Takaya H, Ariyo K 2017 Behavior of toxicity in river basins dominated by residential areas Contemporary Engineering Sciences 10 (7), 305-315.

[9] Rusnugroho, A. 2012. QUAL2Kw as a Program For Calculating The Pllution Load Capacity in Madiun City. (in bahasa indonesia)

[10] Sanitation and Enviromental Offices. 2016. Water Quality Parameter. Palembang. (in bahasa Indonesia)

[11] Sugiharto. 1987. Fundamentals of Wastewater Management; UI Press. Jakarta. (in bahasa Indonesia).

[12] Yamashita H, Haribowo R, Sekine M, Oda N, Kanno A, Shimono Y 2012 Toxicity test using medaka (Oryzias latipes) early fry and concentrated sample water as an index of aquatic habitat condition Environmental Science and Pollution Research 19 (7), 2581-2594. 